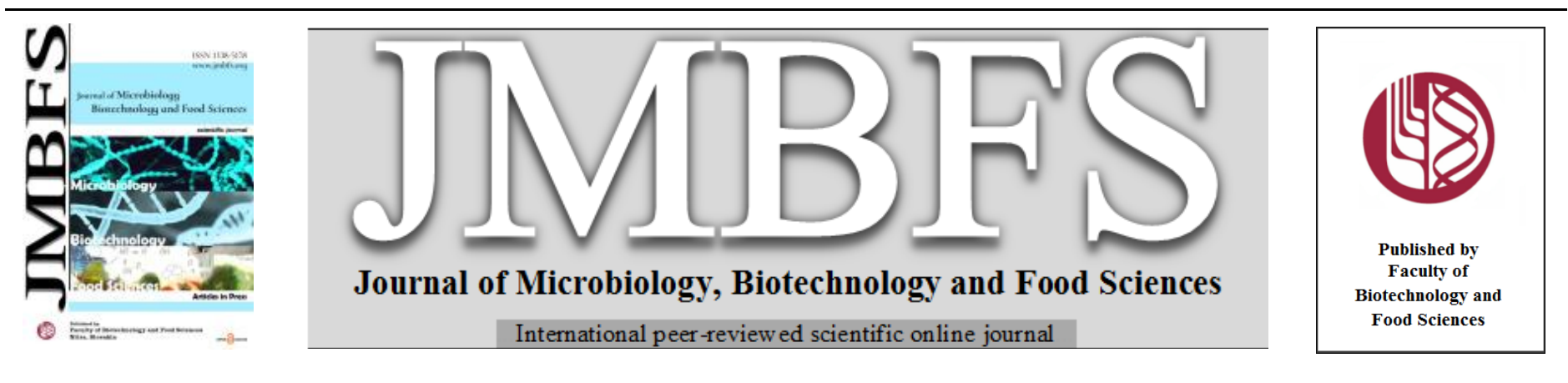

\title{
CHEMICAL CHANGES OF PUMPKIN SEED OILS AND THE IMPACT ON LIPID STABILITY DURING THERMAL TREATMENT: STUDY BY FTIR - SPECTROSCOPY
}

\author{
Fatos Rexhepi ${ }^{1,}$, Aziz Behrami ${ }^{1}$, Cristina Samaniego-Sánchez ${ }^{2}$, Maksim Rebezov ${ }^{3,4}$ Mohammad Ali Shariati ${ }^{4}$, Artur Bastian da Silva ${ }^{5}$, \\ Sávio Leandro Bertoli ${ }^{5}$ and Carolina Krebs de Souza ${ }^{5 *}$
}

\author{
Address(es): \\ ${ }^{1}$ Faculty of Food Technology, University of Mitrovica “Isa Boletini” Ukshin Kovaqica, 40000, Mitrovica, Kosovo. \\ ${ }^{2}$ Department of Nutrition and Bromatology, Pharmacy Faculty UGR, 10871, Granada, Spain. \\ ${ }^{3}$ Department of Scientific Research, V. M. Gorbatov Federal Research Center for Food Systems, 109316 Moscow, Russian Federation. \\ ${ }^{4}$ Department of Scientific Research, K.G. Razumovsky Moscow State University of technologies and management (The First Cossack University), 73, Zemlyanoy Val \\ St., Moscow, 109004, Russian Federation. \\ ${ }^{5}$ Department of Chemical Engineering, University of Blumenau, 89030-000, Blumenau, Santa Catarina, Brazil.
}

*Corresponding author: carolinakrebs@ @urb.br; shariatymohammadali@gmail.com

https://doi.org/10.55251/jmbfs.5839

\section{ARTICLE INFO}

Received 16. 11. 2021

Revised 10. 2. 2022

Accepted 15. 2. 2022

Published 1. 6. 2022

Regular article

OPEN $\partial_{\text {ACCESS }}$

\begin{abstract}
Oxidative stability and fatty acid composition of the pumpkin seed oil (PSO) were studied, during roasting process from 80 to $150{ }^{\circ} \mathrm{C}$ and oil heat treatment $\left(220{ }^{\circ} \mathrm{C}\right.$ ), by FTIR (Fourier - transform infrared) - Spectroscopy and GC/MS (Gas chromatography - mass spectrometry). The physicochemical parameters (density and iodine value) showed a significant increase $(\mathrm{p}<0.05)$ during roasting, with a maximum value observed in the oil roasted at temperatures from 90 to $110{ }^{\circ} \mathrm{C}$. The relative contents of polyunsaturated fatty acids (PUFAs) decreased to $87.7 \%$, and saturated fatty acids (SFAs) increased to $112.5 \%$ at unroasted sample, after thermal treatment of oil samples. Especially at temperature 90 and $110{ }^{\circ} \mathrm{C}$, oil samples have demonstrated that relative contents of PUFAs decreased to $95 \%$ and SFAs increased to $101.6 \%$. FTIR Spectroscopy provide to understand mechanism of chemical changes of seed during roasting process and, as result, which of obtained compounds are responsible for increasing thermal stability of oil lipids. In this study, it was observed that the best temperature for roasting pumpkin seeds is $110{ }^{\circ} \mathrm{C}$, since at this point, both oxidation and Maillard reactions give rise to compounds with maximum antioxidant effect (lipid stability).
\end{abstract}

Keywords: Pumpkin seed oil; Ratio frequency; Maillard reaction; FTIR-Spectroscopy; GC/MS

\section{INTRODUCTION}

Pumpkin seed oil (PSO) from varieties Cucurbita Pepo L. pumpkin seed without shell, usually it used as a flavoured salad oil, is originated especially from Styria region in Austria and other European countries (Fruhwirth and Hermetter, 2007). During roasting of pumpkin seeds, variations in chemical composition are observed relation to the unroasted flavor, especially the nutty flavor, whose properties obtained are from oxidized compounds, identified after the roasting process (Murkovič et al., 2004; Siegmund and Murkovič, 2004).

Cooking is a necessary process before the consumption of many vegetables. It allows the improvement of sensory, nutritionals and safety features, as well as modifies the phytochemical digestibility (Samaniego-Sanchéz et al., 2021) Researches highlights the importance of pre-roasting treatments to improve the quality of oil, attributing greater antioxidant effect (Nguyen, 2020) and higher lipid stability (Ali et al., 2017; Aktaş et al., 2018). Roasting process is crucial for obtaining necessary chemically changes of pumpkin seed oil, with best temperatures from 90 to $130{ }^{\circ} \mathrm{C}$, shows maximum anti-radical activity at $110{ }^{\circ} \mathrm{C}$ (Potočnik et al., 2018). For formation of responsible compounds for nutty roasted aroma, temperatures above $100{ }^{\circ} \mathrm{C}$ are applied. These compounds can be originated from of three reactions, which can occur during roasting process of pumpkin seed such as Strecker degradation, lipid peroxidation and Maillard reaction (Siegmund \& Murkovič, 2004).

During roasting process of pumpkin seed, most of aldehydes compounds are product of strecker degradation and lipid peroxidation, which occur around 100 ${ }^{\circ} \mathrm{C}$. Furan derivative compounds can be a product of lipid peroxidation and most of pyrazines can be of Maillard Reaction (Siegmund \& Murkovič, 2004).

Roasting process of pumpkin seed results in chemical transformations, producing the mixture of different compounds that can play role of protective agents against lipid oxidation or their degradation (Potočnik et al., 2018; Namiki et al., 1988), which ensures higher antioxidant activity or stability of roasted pumpkin seed oil. Challenge of this research is to use FTIR-Spectroscopy, GC/MS and some physicochemical parameters to obtain more information about chemical reactions during roasting, as well as monitoring the stability of pumpkin seed oil, by determining exactly at which roasting temperature the oil has the lowest level lipid oxidation or degradation.

There is several information in the literature about chemical changes in pumpkin seed during roasting, including the three type of reactions which occur during this process and their correlation with these chemical changes (oil stability and antioxidant capacity) during roasting temperature, where the chemical transformations are at their maximum activity. However, there is still unknown if all three reactions occur simultaneously in each roasting stage, and which would be the main reaction.

Nevertheless, detailed investigation of stability of roasted PSO, which determine responsible components for this antioxidant effect, will not be complete if are not involve the chemical changes in seed during roasting and determine the main reaction which occurs at every temperature, to then find interconnection between chemical composition and oil stability.

Therefore, the first aim of this study is to determine in which temperature the main reaction occurs (Strecker degradation, Maillard reaction, Lipid peroxidation or some of their correlation) using FTIR Spectroscopy and compare, by analysis of physicochemical parameters and GC/MS, the oil samples. The second aim is to verify the stability of unroasted and roasted PSO, at different temperatures, to determine in which temperature the oil shows higher stability.

\section{MATERIAL AND METHODS}

\section{Material and chemicals}

Pumpkin seed samples (Cucurbita pepo L) were obtained from Peja city (Kosovo) in 2019. Reagents used were iodobromine (IBr), glacial acetic acid $\left(\mathrm{CH}_{3} \mathrm{COOH}\right)$, potassium iodide (KI), sodium thiosulphate $\left(\mathrm{Na}_{2} \mathrm{~S}_{2} \mathrm{O}_{3}\right)$, n-hexane $\left(\mathrm{CH} 3\left(\mathrm{CH}_{2}\right)_{4} \mathrm{CH}_{3}\right)$, sodium methoxide $\left(\mathrm{CH}_{3} \mathrm{ONa}\right)$ - FAME standard purity $(\geq 99$ $\%)$. All chemical reagents were purchased from Sigma-Aldrich, Germany. 


\section{Roasting conditions and oil extraction}

Pumpkin seed were roasted in electric oven at $80{ }^{\circ} \mathrm{C}, 90{ }^{\circ} \mathrm{C}, 110^{\circ} \mathrm{C}, 130{ }^{\circ} \mathrm{C}$ and $150{ }^{\circ} \mathrm{C}$ (Potocnik et al., 2018). The cold-pressed extraction of pumpkin seed oil, unroasted and roasted, was performed using a screw press (Koçmaksan, KMS10, Izmir, Turkey), according to Nederal et al. (2014).

\section{Thermal oxidation - Thermal treatment process}

Obtained oil from unroasted and roasted seeds samples (100 g), was inserted into $200 \mathrm{~mL}$ beckers, placed in an electric oven and thermally treated at $220{ }^{\circ} \mathrm{C}(10$ $\min )$.

\section{Density measurements}

Densities of all oil samples, before roasting of their seeds and after thermally treated, were measured by an R.D bottle with a capacity of $5 \mathrm{~mL}$ (Zahir et al. 2017).

\section{Iodine value (IV) measurements}

A known weight of the oil sample was treated with iodobromine (IBr), in solution media of glacial acetic. Unreacted iodobromine, then react with potassium iodide, which converts it to iodine, which will be determined by titration with standard fresh prepared solution of sodium thiosulphate. Calculation of iodine value (equation 1):

$$
I V=(b-v) * C * 126.9 * 100 / v * 1000 \quad \text { (Eq. } 1)
$$

Where: $b$ is the volume of thiosulphate used for blank sample, $v$ is the volume of thiosulphate for real sample, $C$ is the concentration of thiosulphate prepared solution, $w$ is the weight of the real oil sample and 126.9 is the molecular weight of iodine (Singh, Gupta \& Bajpai, 1981).

\section{Spectral analysis}

The results of thermal stability of the oil, obtained before and after roasting of the seeds, were recorded using instrument equipped with high sensitivity deuterated triglyceride sulphate (DTGS) - by FTIR detector (IRAffinity-1S Shimadzu Corporation, Kyoto, Japan). Samples were deposited in a CaF2 transparent cell, spectroscopy running between $1000-4000 \mathrm{~cm}^{-1}$, with 32 scans, resolution of $4 \mathrm{~cm}$ 1 and recorded spot spacing of approximately $1.9 \mathrm{~cm}^{-1}$. Peak intensity was calculated by FTIR IR Solution software.

\section{Fatty acid composition}

Fatty acid methyl esters (FAMEs) were prepared, based on standard method 5509 (ISO) 1978 with minor modification described as follows: Weighted mass of 25 mg of oil samples were dissolved in $10 \mathrm{~mL}$ hexane and shaken. Then, $1 \mathrm{~mL}$ of sodium methoxide dissolved in methanol, with concentration $5.4 \mathrm{~mol} \mathrm{dm}{ }^{-3}$, were added in each of oil samples and mixed (60 seconds). After phase separation, from each sample, were collected supernatant for GC/MS analysis. The GC/MS used for FAME analysis was perform using a 7890A gas chromatograph equipped with auto sampler model 7693 and a 5975C MS detector (Agilent, Santa Clara, CA, USA). Used capillary column was DB-23 (50\% bonded ciano polysiloxane $60 \mathrm{~m}$ x $0.25 \mathrm{~mm}$ i.e. $\mathrm{x} 0.25 \mu \mathrm{m}$ stationary phase) and a helium as a carries gas. The split ratio mode of the sample was $1 / 25$ and the injection volume was $3 \mu \mathrm{L}$ for each analyzed sample. The temperatures of the GC system were the following: injector temperature $250{ }^{\circ} \mathrm{C}$; transfer line temperature $280{ }^{\circ} \mathrm{C}$; oven temperature program: $50{ }^{\circ} \mathrm{C}(2 \mathrm{~min})-30{ }^{\circ} \mathrm{C} / \mathrm{min}-200{ }^{\circ} \mathrm{C}-20{ }^{\circ} \mathrm{C} / \mathrm{min}-230{ }^{\circ} \mathrm{C}(15 \mathrm{~min})$. Identifying and quantifying every peaks has been carried out in comparison with peaks of standard FAME, on their retention times, with those of external standards.

\section{Statistical analysis}

Statistical analyses were performed using the software Statistica (version 7.0, StatSoft Inc., Oklahoma, USA) (Hoffmann et al., 2021a,b,c). Normal distribution and variance homogeneity had been previously tested (Shapiro-Wilk). The experimental data were analysed by ANOVA, with the mean comparison (Tukey's test). The difference was considered significant if $p<0.05$. All measurements were performed in triplicate and the results were reported as the mean \pm one standard deviation.

\section{RESULTS AND DISCUSSION}

Pumpkin seed samples were wet salted and roasted at different roasting temperatures $\left(80,100,120,130\right.$ and $150{ }^{\circ} \mathrm{C}$ ) (Potocnik et al., 2018). The oil samples of unroasted and roasted seeds, were submitted to analysis of density, iodine value, FTIR spectroscopy, Chromatography (FAME) and oxidative stability.

\section{Density measurements}

Vegetable oils are mixture of different triglycerides (TGs) and their density depends from nature of TGs, as well as of other compounds, which could be present in oils of different origins (Ramírez-Anaya et al., 2019; Ramírez-Anaya et al., 2015).

Density decreased linearly after increasing temperature due to the thermal expansion but continuously heating of oil, after its repeated thermal treatment, in general increases its value (Hoffmann et al., 2018; Kalogianni et al., 2011) During oil heat treatment, transformations of triglycerides occur, such as oxidation or polymerization. Density decreases with increasing unsaturation level, and the opposite occurs with increasing saturation and polymerization level (Kim et al. 2010).

Oxidised compounds originating, from those reactions, such as aldehydes, ketones, hydroperoxides or other unknown polymer compounds, may have higher or lower molecular weight compare to TGs, whose chemical changes will have impact in density changes. Paul \& Mittal (1996) reported about occurring polymerization during heating of the oil and observed that the density increased. The oxidation and saturation of TG's is the first stage before polymerization process in edible oils (Choe \& Min, 2006). A completely different chemical transformation occurs in pumpkin seeds during their roasting, because there is a mixture of compounds such as proteins, TGs, and natural constituents, which results in several chemical interactions.

Figure 1 shows the behaviour of the density of the oil, obtained from cold pressing of the pumpkin seeds, before and after roasting at different temperatures and after oil thermal treatment. At first sample (0), unroasted seeds, density is lower $(0.90$ g.cm-3) and gradually increased to maximum level $\left(0.96 \mathrm{g.cm}{ }^{-3}\right)$ at seed roasting temperature at $90{ }^{\circ} \mathrm{C}$. From this density changes, it can confirm that sample roasted at $90^{\circ} \mathrm{C}$ contain higher level of oxidised or saturated compounds compare to, unroasted sample and roasted at $80^{\circ} \mathrm{C}$ (Kim et al., 2010). From this point of view, during roasting up to $90^{\circ} \mathrm{C}$, lipid peroxidation occurs, which results in lipid compounds of higher molecular weight in the first stage, which may subsequently decompose and produce other oxidised compounds with lower molecular weight (aldehydes, ketones, alcohol). This would increase the concentration of saturated fatty acids and consequently, the density of the oil (Barthel \& Grosch, 1974; Zahir et al., 2017).

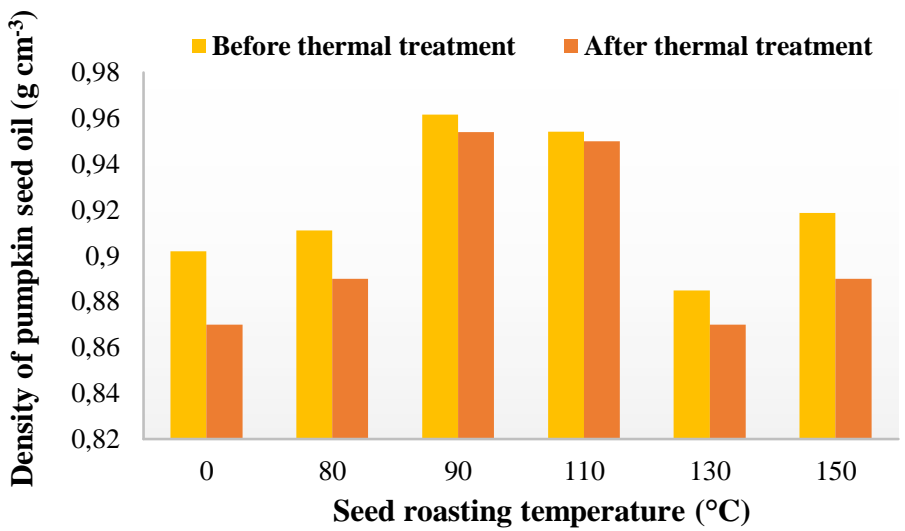

Figure 1 Pumpkin seed oil density, before (0) and after roasted (80, 90, 110, 130 and $150{ }^{\circ} \mathrm{C}$ ), and before and after thermal treatment at $220^{\circ} \mathrm{C}$.

The oil samples of roasted seeds at 90 and $110^{\circ} \mathrm{C}$, had presented similar densities $\left(0.95{\mathrm{~g} . \mathrm{cm}^{-3}}^{-3}\right.$. However, there is a reduction in the density of the samples roasted

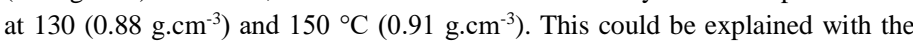
increase of smaller compounds in the mixture, which indicates the formation unknown compounds from complex reaction, which occur in pumpkin seeds during roasting at higher temperature. Only the sample of seed oil roasted at $110^{\circ} \mathrm{C}$ showed lesser difference in density $(p>0.05)$, before and after thermal treatment All the other samples showed a higher density after thermal treatment, possibly due to increased saturation level during thermal treatment or oxidation of their lipids.

\section{Iodine value (IV) measurements}

In Figure 2 it is presented the iodine value of oil samples, before seeds roasting at different temperatures and after seed thermal treatment, for determination of unsaturation level of lipids. The unroasted sample $(0)$ and roasted samples at 80 , 90 and $110{ }^{\circ} \mathrm{C}(p>0.05)$, present similarity in iodine value, while the samples 
roasted at higher temperature $\left(130\right.$ and $\left.150{ }^{\circ} \mathrm{C}\right)$ showed a significant decrease of iodine value (110 and 98, respectively).

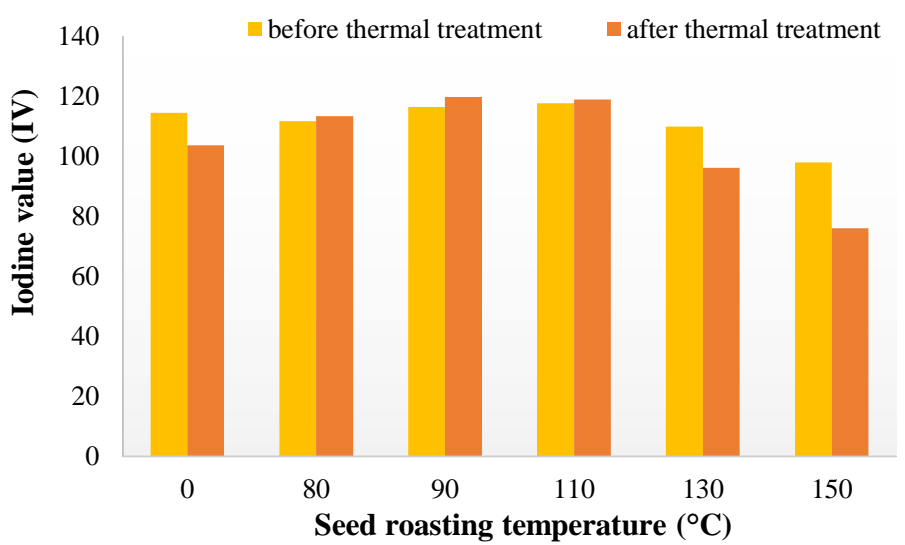

Figure 2 Pumpkin seed oil iodine value, before ( 0 ) and after roasted $(80,90,110$ 130 and $150{ }^{\circ} \mathrm{C}$ ), and before and after thermal treatment at $220^{\circ} \mathrm{C}$.

The iodine value, of the same samples, was analyzed before and after thermal treatment, to check the stability of the oil. Before thermal treatment, the oil unroasted seed sample presents approximately the same iodine value $(p>0.05)$ as that of the samples roasted at 80,90 and $110^{\circ} \mathrm{C}(115 \pm 2.7)$. However, unroasted samples, after thermal treatment, decreases iodine value, except the samples roasted at 80,90 and $110{ }^{\circ} \mathrm{C}$, especially at $110^{\circ} \mathrm{C}$, whose iodine value, after thermal treatment, increases slightly. This means that the oil obtained from pumpkin seed at this roasting temperature, is more stable compared to the oil obtained from the unroasted sample (Nederal $\boldsymbol{e t}$ al., 2012).

\section{Spectral analysis}

FTIR spectra of oil samples, obtained from pumpkin seed roasted process, was used as indicator for lipid oxidation and as a basis for calculating the peak ratio $3007 / 2854$. That methodology is used to characterize edible oils and fats since they differ in the intensity and exact frequency at which the transmittance or absorbance band maximum occurs, according to the composition and nature of the sample (Guillen and Cabo, 2000). Peak $3007 \mathrm{~cm}^{-1}$ (Figure 3 ) present cis double bond (=C$\mathrm{H})$ and normally during oxidation of this double bond, this will be converted in single methylene bond $\left(2854 \mathrm{~cm}^{-1}\right)$. That mean if we use ratio of these, the same could be interesting indicator in the case of ratio decreasing, which could be understands as the occur lipid peroxidation (Guillen \& Cabo, 2000).

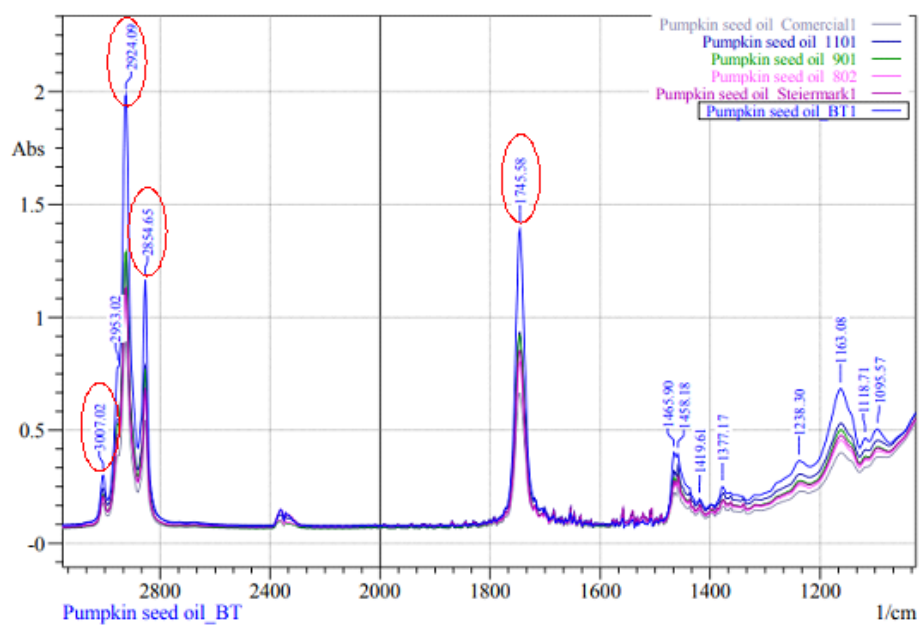

Figure 3 FTIR Spectra of pumpkin seed oil.

If double bonds are part of triglyceride compounds in that case could be used ratio $3007 / 1745$ (Figure 4), because peak $1745 \mathrm{~cm}^{-1}$ it is a vibration of carbonyl group $(\mathrm{C}=\mathrm{O})$ ester functional group, representative as triglyceride compounds (Rexhep et al., 2019; Guillen \& Cabo, 2000). This ratio could be used as a second confirmation indicator for lipid peroxidation because vegetable oils composition is more than $95 \%$ triglyceride and usually most of double bonds are part of triglyceride (Hoffmann et al., 2018). In Figure 4 are presented changes of both ratios, which are in same tendency of behaviur, and again would confirm that monitored double bonds are part of triglyceride composition and chemical transformation occur inside triglyceride molecules.

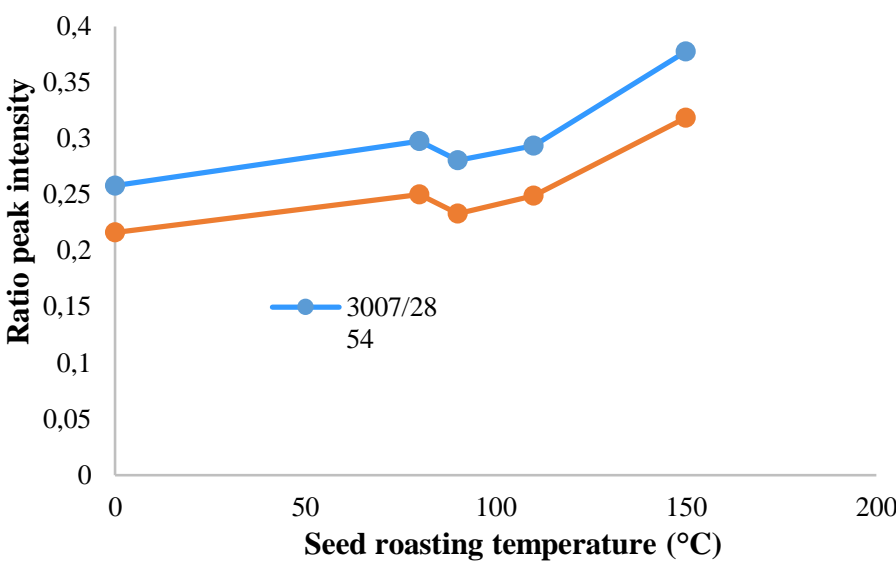

Figure 4 Behavior of the ratio intensity, of oil obtained from pumpkin seed unroasted $(0)$ and roasted, at $80,90,110,130$ and $150{ }^{\circ} \mathrm{C}$.

First monitored point is the unroasted sample and second point is the sample after roasting at $80{ }^{\circ} \mathrm{C}$, which has increased ratio compare to the previous sample. This could be explained with the evaporation of volatile compounds that, in general, indicates that the level of unsaturated composition has increased. Next monitored sample is the roasted at $90{ }^{\circ} \mathrm{C}$, which present lower level of this ratio, which confirm of lipid peroxidation occurred during roasted at this temperature. In this process, slightly increasing proportions of lipid peroxidation were observed, in addition to the percentage increase of the unsaturated composition.

Increasing of unsaturated level from roasted sample at $110{ }^{\circ} \mathrm{C}$ was observed as a rapidly changes. These unexpected changes could be explained by the occurrence of lipid peroxidation at roasting temperature from 80 to $100{ }^{\circ} \mathrm{C}$ and their products could have other unsaturated chemical bonds which contribute in increasing in presented ratio.

Figure 5 present changes of three intensity bands, which are responsible for Maillard reaction, where occur same time, increased carbonyl group of triglyceride $1745 \mathrm{~cm}^{-1}$ and methylene group in two band symmetric and asymmetric stretching vibration, 2924 and $2853 \mathrm{~cm}^{-1}$ (Calabrò \& Magazù, 2012). Intensity main increasing, for three bands same time, can be seen in third sample after roasting $\left(90{ }^{\circ} \mathrm{C}\right)$. This fact stands out because only one stage occurs after lipid peroxidation. From this point of view Maillard reaction occur immediately after the end of lipid peroxidation, which as a primary reaction it seems to induce induces the Maillard reaction.

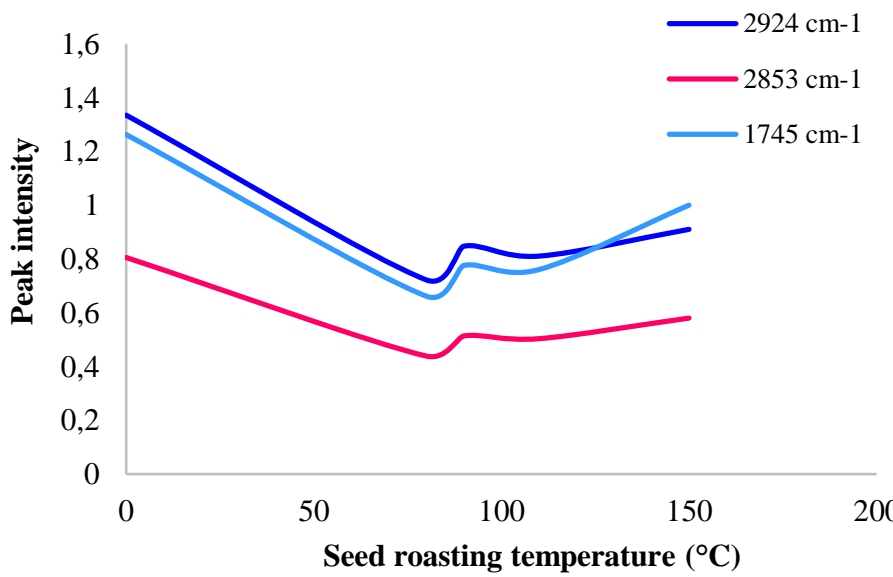

Figure 5 Changes of three vibrational band responsible for Maillard reaction, of oil obtained from pumpkin seed unroasted $(0)$ and roasted at 80, 90,110,130 and $150{ }^{\circ} \mathrm{C}$.

As conclusion for this mechanism, Maillard reaction start after the end of lipid peroxidation, that mean product obtained from lipid peroxidation play a role as a precursor for initiate the Maillard reaction. In general this indicate the interaction between carbonyl group of different sugars isomers or same group from other compounds, and free amino group from protein or individual aminoacids (Maillard, 1912).

Maillard products are responsible for nutty roasted aroma and based on the mechanism they are not possible to be obtained if not happened first lipid peroxidation and their product to be as a precursor for Maillard reaction. Maillard reaction it is still active after sample roasting at $110^{\circ} \mathrm{C}$, but not to the same degree as the previous sample $\left(90{ }^{\circ} \mathrm{C}\right)$. After roasting temperature at $130{ }^{\circ} \mathrm{C}$, they no longer occur. Strecker degradation it is another possibility for aminoacids converts in aldehyde, but not under interaction with sugars like Maillard reaction. 
Strecker reaction involve oxidative deamination and decarboxylation of aminoacids in the presence of dicarbonyl compounds, whose formed components are aldehyde with one less carbon atom than the original amino acid (Whitfiel, 1992). Resulting compounds from Strecker degradation have low odour and teste thresholds. For this reason, they are important components for the final aroma of the food, drink or in this case vegetable oil. Anyway still is unknown if during pumpkin seed roasting process occurring Strecker degradation or not because any characteristic indicator isn't selective just for product of Strecker degradation applied in complex food samples such as pumpkin seed. Aldehyde products could be as resulting compounds from Strecker degradation and from Maillard reactions. From this point of view, occurring of Strecker degradation during pumpkin seed roasting is a topic, whose occurrence, has been little detailed and proven by the scientific community.

Considering the possibility that this reaction also occurs during seed roasting, it would be important to understand which reaction predominates, to explain these mechanisms and the possibility that Strecker degradation interacts with other chemical transformations.

To monitor thermal oxidative stability level, of PSO, for each roasted sample at different temperature and compare with same samples after thermal treatment, was used FTIR band of frequency ratio $3007 / 2854 \mathrm{~cm}^{-1}$, which is used indicator for oxidation level of lipids. As can be seen in Figure 6, in general all heat-treated samples have higher oxidation degree, this can be explained probably because during their thermal treatment evaporate most of volatile compounds which change their oxidation level and as a result increases the concentration of unsaturated compounds.

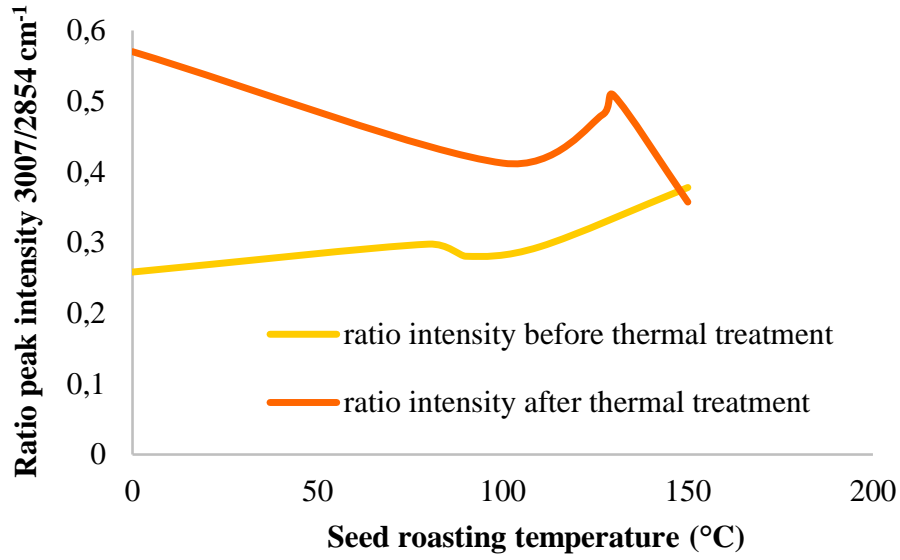

Figure 6 Ratio of intensity $3007 / 2854 \mathrm{~cm}^{-1}$ for pumpkin seed oil, before and after thermal treatment (oxidative stability).

Roasted sample has low difference ratio, before and after thermal treatment, compare with unroasted, which has higher ratio difference before and after therma treatment. This can be explain if roasted sample, at temperature from 80 to $130{ }^{\circ} \mathrm{C}$, contain compounds with high antioxidant effect, which protect lipids from oxidation. Sample roasted at $150{ }^{\circ} \mathrm{C}$ rapidly decreases ratio of frequencies, and this mean decrease of unsaturated level of lipids is because occur oxidation of double bonds in lipid structure. In this case, oxidised compounds are insufficient to protect lipid oxidation, because they could be decomposed or they changed chemically. Another FTIR important band is frequency from $3000-3020 \mathrm{~cm}^{-1}$, characteristic from double bonds $(=\mathrm{C}-\mathrm{H})$, which indicates of triglycerides unsaturation level (lipid oxidation) (Vlachos et al., 2006).

Figure 7 presents the changes of peak area, referring to the oxidative stability of the pumpkin seed oil samples, unroasted and roasted, before and after thermal treatment $\left(220^{\circ} \mathrm{C}\right)$.

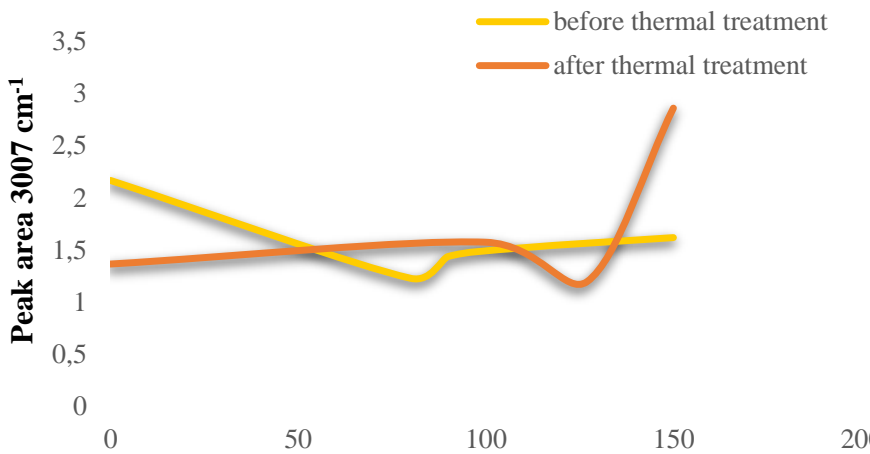

Seed roasting temperature $\left({ }^{\circ} \mathrm{C}\right)$

Figure 7 Peak area of band $3007 \mathrm{~cm}^{-1}$ for pumpkin seed oil before and after therma treatment (oxidative stability).

Only unroasted sample presented higher difference before (1.36) and after (2.17) thermal treatment, which confirm the lipid instability of this sample compare to roast. Less variation is observed in the values, before and after thermal treatment, of samples roasted from $90^{\circ} \mathrm{C}$ to $110^{\circ} \mathrm{C}$, indicating greater lipid stability in this temperature range, compared to samples roasted above $110^{\circ} \mathrm{C}$ (Ibsch et al., 2019). It is possible that at higher temperatures unknown reactions start to occur during roasting of the seeds. Enzyme inactivation, described as responsible for the degradation of oils obtained after heat treatment of seeds, is a factor that could explain the increased lipid stability of roasted pumpkin seed oil (Durmaz \& Gökmen, 2010; Ibisch et al., 2019; Schmitz et al., 2021). However, based on this research, enzyme inactivation would not explain the oxidative stability being higher in samples roasted from 80 to $130^{\circ} \mathrm{C}$, since from this temperature the stability of the oil decreases. For this reason, it is believed that roasted PSO, presents products that contribute to oxidative stability, with antioxidant effect, up to the roasting temperature from 80 to $130{ }^{\circ} \mathrm{C}$ (especially $110{ }^{\circ} \mathrm{C}$ ).

Researchers found higher total polyphenols contents, in oil obtained from roasted pumpkin seed, and reported formation of different antioxidant compounds (Nawirska-Olszańska et al., 2013), probably, from Maillard reaction, which most of them can have protective activity on lipid oxidation (Nederal et al., 2012; Veronezi \& Jorge, 2012). Murkoviç \& Pfannhauser (2020) also investigated about stability of pumpkin seed oil after roasting, and they evidenced the influence of the ratio of linoleic and oleic acid in their lipids. These researchers emphasize the importance of studies on the oxidative behaviour after roasting of pumpkin seeds, as many antioxidant compounds are present after the roasting process.

FTIR - Spectroscopy, as a sensitive tool for monitoring lipid peroxidation, was applied using ratio intensity of different frequencies, to verify chemical correlations (Rexhepi et al., 2019; Guillen \& Cabo, 2000). This tool has also been used to detect the Maillard Reaction by monitoring the intensity of the carbonyl group of triglycerides and methylene group of aliphatic hydrocarbons. When both intensity frequencies increase, it can be attributed to the partial occurrence of the Maillard reaction (Calabrò \& Magazù, 2012).

\section{Fatty acid composition}

Fatty acids levels are showed in Table 1. The main fatty acids in the pumpkin seed oil samples are linoleic acid, oleic acid, palmitic acid, stearic acid. The average of fatty acid content in analyzed samples varies around $99 \%$, which is higher than those published by Nederal et al. (2012)

Table 1 Fatty acid composition (\%) of unroasted and roasted pumpkin seed oils, before thermal treatment at $220^{\circ} \mathrm{C}$.

\begin{tabular}{|c|c|c|c|c|c|c|}
\hline \multirow[b]{2}{*}{ Fatty acids } & \multicolumn{6}{|c|}{ Roasting temperature $\left({ }^{\circ} \mathrm{C}\right)$} \\
\hline & unroasted & 80 & 90 & 110 & 130 & 150 \\
\hline Lauric (C12:0) & $0.02 \pm 0.01^{\mathrm{a}}$ & $0.02 \pm 0.01^{\mathrm{a}}$ & $0.02 \pm 0.01^{\mathrm{a}}$ & $0.02 \pm 0.01^{\mathrm{a}}$ & $0.02 \pm 0.01^{\mathrm{a}}$ & $0.02 \pm 0.01^{\mathrm{a}}$ \\
\hline Myristic (C14:0) & $0.10 \pm 0.01^{\mathrm{a}}$ & $0.10 \pm 0.01^{\mathrm{a}}$ & $0.10 \pm 0.01^{\mathrm{a}}$ & $0.09 \pm 0.01^{\mathrm{a}}$ & $0.09 \pm 0.01^{\mathrm{a}}$ & $0.10 \pm 0.01^{\mathrm{a}}$ \\
\hline Palmitic (C16:0) & $11.16 \pm 0.01^{\mathrm{a}}$ & $11.17 \pm 0.01^{\mathrm{a}}$ & $11.23 \pm 0.01^{\mathrm{a}}$ & $11.28 \pm 0.01^{\mathrm{a}}$ & $11.53 \pm 0.01^{\mathrm{a}}$ & $11.48 \pm 0.01^{\mathrm{a}}$ \\
\hline Palmitoleic (C16:1) & $0.12 \pm 0.02^{\mathrm{b}}$ & $0.11 \pm 0.02^{\mathrm{b}}$ & $0.11 \pm 0.02^{\mathrm{b}}$ & $0.11 \pm 0.02^{\mathrm{b}}$ & $0.15 \pm 0.01^{\mathrm{a}}$ & $0.12 \pm 0.02^{\mathrm{ab}}$ \\
\hline Heptadecanoic (C17:0) & $0.07 \pm 0.02^{\mathrm{a}}$ & $0.06 \pm 0.01^{\mathrm{a}}$ & $0.06 \pm 0.001^{\mathrm{a}}$ & $0.06 \pm 0.01^{\mathrm{a}}$ & $0.07 \pm 0.01^{\mathrm{a}}$ & $0.07 \pm 0.01^{\mathrm{a}}$ \\
\hline Stearic (C18:0) & $9.69 \pm 0.01^{\mathrm{a}}$ & $9.73 \pm 0.01^{\mathrm{a}}$ & $9.73 \pm 0.01^{\mathrm{a}}$ & $9.72 \pm 0.01^{\mathrm{a}}$ & $9.72 \pm 0.01^{\mathrm{a}}$ & $10.06 \pm 0.05^{\mathrm{a}}$ \\
\hline Oleic (C18:1) & $36.54 \pm 0.03^{\mathrm{a}}$ & $36.75 \pm 0.03^{\mathrm{a}}$ & $36.81 \pm 0.03^{\mathrm{a}}$ & $36.50 \pm 0.03^{\mathrm{a}}$ & $37.31 \pm 0.03^{\mathrm{a}}$ & $36.19 \pm 0.03^{\mathrm{a}}$ \\
\hline Linoleic (C18:2) & $41.33 \pm 0.04$ & $41.27 \pm 0.04$ & $41.27 \pm 0.04$ & $41.17 \pm 0.04^{\mathrm{a}}$ & $40.36 \pm 0.04^{\mathrm{a}}$ & $41.19 \pm 0.05^{\mathrm{a}}$ \\
\hline Linolenic (C18:3) & $0.13 \pm 0.01^{\mathrm{b}}$ & $0.13 \pm 0.01^{\mathrm{b}}$ & $0.13 \pm 0.01^{\mathrm{b}}$ & $0.13 \pm 0.01^{\mathrm{b}}$ & $0.18 \pm 0.01^{\mathrm{a}}$ & $0.17 \pm 0.01^{\mathrm{a}}$ \\
\hline Arachidic (C20:0) & $0.53 \pm 0.01^{\mathrm{b}}$ & $0.52 \pm 0.01^{\mathrm{b}}$ & $0.52 \pm 0.01^{\mathrm{b}}$ & $0.50 \pm 0.01^{\mathrm{b}}$ & $0.56 \pm 0.01^{\mathrm{a}}$ & $0.58 \pm 0.01^{\mathrm{a}}$ \\
\hline$\Sigma$ Saturated & $21.87^{\mathrm{a}}$ & $21.66^{\mathrm{a}}$ & $21.66^{\mathrm{a}}$ & $21.546^{\mathrm{a}}$ & $21.98^{\mathrm{a}}$ & $22.31^{\mathrm{a}}$ \\
\hline$\Sigma$ Monounsaturated & $36.66^{\mathrm{a}}$ & $36.92^{\mathrm{a}}$ & $36.92^{\mathrm{a}}$ & $36.60^{\mathrm{a}}$ & $37.46^{\mathrm{a}}$ & $36.31^{\mathrm{a}}$ \\
\hline ¿Polyunsaturated & $41.46^{\mathrm{a}}$ & $41.40^{\mathrm{a}}$ & $41.40^{\mathrm{a}}$ & $41.84^{\mathrm{a}}$ & $40.54^{\mathrm{a}}$ & $40.36^{\mathrm{a}}$ \\
\hline $\mathrm{P} / \mathrm{S}$ ratio & $1.89^{\mathrm{a}}$ & $1.90^{\mathrm{a}}$ & $1.91^{\mathrm{a}}$ & $1.94^{\mathrm{a}}$ & $1.84^{\mathrm{a}}$ & $1.85^{\mathrm{a}}$ \\
\hline
\end{tabular}

Means \pm standard deviation fatty acid composition of pumpkin seed oils.

Different lowercase letters on the same line indicate a significant difference at the $5 \%$ level by Tukey's test. 
The fatty acid profile of vegetable oils influences its physical properties during treatment, especially levels of viscosity and heat transfer properties (Debnath, Vidyarthi \& Singh, 2010). Usually during oil heating occur lipid oxidation, increasing the concentration of saturated fatty acids and decreasing of unsaturated fatty acids, which is probably a result from PUFA conversion in MUFA and SFA (Henna \& Tan, 2009). Its degree of unsaturation however, modifies the stability during thermal treatment (Contreras-Gallegos et al., 2017).

An increase in the percentage of palmitic and stearic acid in the oil obtained after roasting the seeds is observed as the roasting temperature increases. Except the sample at $150{ }^{\circ} \mathrm{C}$, whose palmitic acid does not maintain this trend. However, linoleic acid decreased its percentage as the roasting temperature increased, except in the sample roasted at $150^{\circ} \mathrm{C}$.

Usually unsaturated fatty acids during oxidation are converted to saturated corresponding fatty acid but the percentage of oleic acid, on the other hand, did not correlate with the increase in roasting temperature, probably due to the different reactions that may occur at different temperatures. These results in the percentages of fatty acids, indicate that the expected oxidation did not occur, since other reactions may occur at different stages and temperatures of the roasting process (Lee, Kim, \& Choe, 2007). This was also confirmed by the percentages total of saturated and unsaturated fatty acids that also showed unexpected variations. In general, the percentage SFA increased as the percentages PUFA and MUFA decreased, especially during roasting at higher temperatures. It is important to note that this usually happens at higher roasting temperatures, where completely different reactions probably occur than at lower temperatures. The $\mathrm{P} / \mathrm{S}$ ratio is also important, as when it has decreased, it indicates that there has been lipid oxidation in the oil sample. The unexpected values of this parameter increase in the sample roasted at $110^{\circ} \mathrm{C}$, which could be explained by lipid peroxidation reactions and Maillard reaction that occur especially in this temperature range. Probably these reactions are in the intermediate stage where polyunsaturated fatty acids are not converted into saturated fatty acids. According to Raczyk et al. (2017), roasting of pumpkin seed at temperature from 100 to $130^{\circ} \mathrm{C}$, present higher oxidative stability of obtained oil, without any effect at the composition on their fatty acid.

\section{CONCLUSION}

For all the studied samples, before and after roasting, the obtained oil showed a change in density, which demonstrates the occurrence of oxidation and saturation especially in the samples whose seeds were roasted from 90 to $110{ }^{\circ} \mathrm{C}$. The iodine value shows similar changes, which confirms that the oil did not change at the saturation level of the sample roasted at $110^{\circ} \mathrm{C}$, reducing its values at higher temperature. Both the density and the iodine value, showed little variation after heat treatment at $220{ }^{\circ} \mathrm{C}$, especially in the roasted seed oil samples at 90 and 110 ${ }^{\circ} \mathrm{C}$, demonstrating greater stability in this temperature range. Based on FTIR measurements ratio intensities band and single band, lipid peroxidation occurs from roasting temperature from 80 to $90^{\circ} \mathrm{C}$, and from 90 to $110{ }^{\circ} \mathrm{C}$ Maillard reaction occurs. Thus, lipid peroxidation compounds are precursors of Maillard reactions. The stability of the oil, in this temperature range, may be correlated to the origin of oxidized compounds that have antioxidant effect. Finally, the best temperature for roasting pumpkin seeds is $110{ }^{\circ} \mathrm{C}$, since at this point, both oxidation and Maillard reactions give rise to compounds with maximum antioxidant effect (lipid stability).

\section{REFERENCES}

Aktas, N., Gerçekaslan, K. E., Uzlasır, T. (2018). The effect of some preroasting treatments on quality characteristics of pumpkin seed oil. Oil seeds Fats Crops Lipids, 25, 2-10. https://doi.org/10.1051/ocl/2018025.

Ali, M.A., Nargis, A., Othman, N.H., Noor AF, Sadik G, \& Hossen J. (2017) Oxidation stability and compositional characteristics of oils from

microwave roasted pumpkin seeds during thermal oxidation. International Journal of Food Properties, 20 (11), 2569-2580.

https://doi.org/10.1080/10942912.2016.1244544

Barthel, G., \& Grosch, W. (1974). Peroxide value determination - Comparison of some methods. Journal of the American Oil Chemists Society,

51(12), 540-544. https://doi.org/10.1007/BF02636025

Calabrò, E., \& Magazù, S. (2012). Comparison between conventional convective heating and microwave heating: an FTIR spectroscopy study

of the effects of microwave oven cooking of bovine breast meat. Journal of Electromagnetic Analysis \& Applications, 4 (11), 433-439. https://doi.org/10.4236/jemaa.2012.411060

Choe, E., \& Min, D. B. (2006). Mechanisms and Factors for Edible Oil Oxidation Comprehensive Reviews in Food Science and Food Safety, 5(4), 169186. https://doi.org/10.1111/j.1541-4337.2006.00009.x

Contreras-Gallegos, E., Domínguez-Pacheco, F. A., Hernández-Aguilar, C., Salazar-Montoya, J. A., Ramos-Ramírez, E. G., Cruz Orea, A. (2017). Specific heat of vegetable oils as a function of temperature obtained by adiabatic scanning calorimetry. J. Therm. Anal. Calorim. 128, 523-531. https://doi.org/10.1007/s10973-016-5864-1
Debnath, S., Vidyarthi, S. K., \& Singh, R. P. (2010). Impact of blending of frying oils on viscosity and heat transfer coefficient at elevated temperatures. J. Food Process. Eng. 33, 144-161. https://doi.org/10.1111/j.1745-4530.2008.00265.x

Durmaz, G., \& Gökmen, V. (2010). Impacts of roasting oily seeds and nuts on their extracted oils. Lipid Technology, 22 (8), 179182. https://doi.org/10.1002/lite.201000042

Fruhwirth, O. G., \& Hermetter, A. (2007). Seeds and oil of the Styrian oil pumpkin: Components and biological activities. Eur. J. Lipid Sci. Technol. 109, 1128 1140. https://doi.org/10.1002/ejlt.200700105

Guillen, M. D., \& Cabo, N. (2000). Some of the most significant changes in the Fourier transform infrared spectra of edible oils under oxidative conditions. Journal of the Science of Food and Agriculture, 80, 2028-2036. https://doi.org/10.1002/1097-0010(200011)80:14<2028::AID-

JSFA713>3.0.CO;2-4

Henna, L. F. S., \& Tan, P. P. A. (2009). Comparative Study of Storage Stability in Virgin Coconut Oil and Extra Virgin Olive Oil Upon Thermal Treatment. International Food Research Journal, 16, 343-354.

Hoffmann, J. F., Vaitilingom, G., Henry, J-F., Chirtoc, M., Olives, R., Goetz, V. Py. X. (2018). Temperature dependence of thermophysical and rheological properties of seven vegetable oils in view of their use as heat transfer fluids in concentrated solar plants. Solar Energy Materials and Solar Cells, 178, 129-138. https://doi.org/10.1016/j.solmat.2017.12.037

Hoffmann, T. G., Ronzoni, A. F., da Silva, D. L., Bertoli, S. L., de Souza, C. K (2021a). Cooling kinetics and mass transfer in postharvest preservation of fresh fruits and vegetables under refrigerated conditions. Chemical Engineering Transactions, 87, 115-120. https://doi.org/10.3303/CET2187020

Hoffmann, T. G., Ronzoni, A. F., da Silva, D. L., Bertoli, S. L., de Souza, C. K (2021b). Impact of household refrigeration parameters on postharvest quality of fresh food produce. Journal of Food Engineering, 306, 110641. https://doi.org/10.1016/j.jfoodeng.2021.110641

Hoffmann,T. G., Angioletti, B. L., Bertoli, S. L., De Souza, C. K. (2021c) Intelligent $\mathrm{pH}$-sensing film based on jaboticaba peels extract incorporated on a biopolymeric matrix. Journal of Food Science and Technology, 104, 1-10 https://doi.org/10.1007/s13197-021-05104-6

Ibsch, R. B. M., Reiter, M. G. R., Bertoli, S. L., \& de Souza, C. K. (2020). Study of pure and combined antioxidants for replacing TBHQ in soybean oil packed in pet bottles. Journal of Food Science and Technology, 57, 821831. https://doi.org/10.1007/s13197-019-04112-x

ISO -International Standard ISO 5509; International Organization for Standardization 1978, 1

Kalogianni, E.P., Karapantsios, T.D., \& Miller, R. (2011). Effect of repeated frying on the viscosity, density and dynamic interfacial tension of palm and olive oil. Journal of Food Engineering, 105(1), 169-179. https://doi.org/10.1016/j.jfoodeng.2011.02.021

Kim, J., Kim, D. N., Lee, S. H., Yoo, S. H., Lee, S. (2010). Correlation of fatty acid composition of vegetable oils with rheological behavior and oil uptake. Food Chem. 118, 398-402. https://doi:10.1016/j.foodchem.2009.05.011.

Lee, J., Kim, M., \& Choe, E. (2007). Antioxidant Activity of Lignan Compounds Extracted from Roasted Sesame Oil on the Oxidation of Sunflower Oil. Food Science and Biotechnology, 16, 981-987.

Maillard, L. C. (1912). Action des acides aminés sur les sucres; formation des mélanoidines par voie methodique. Comptes Rendus de l'Académie des Sciences, 154, 66-68.

Murkovic, M., \& Pfannhauser, W. (2000). Stability of pumpkin seed oil. European Journal of Lipid Science Technology, 102, 607-611. https://doi.org/10.1002/1438 9312(200010)102:10<607::AID-EJLT607>3.0.CO;2-E

Murkovič, M., Piironen, V., Lampi, A. M., Kraushofer, T., Sontag, G. (2004) Changes in chemical composition of pumpkin seeds during the roasting process for production of pumpkin seed oil (part 1: non-volatile compounds). Food Chem. 84, 359-365. https://doi.org/10.1016/S0308-8146(03)00240-1

Namiki, M. (1988). Chemistry of Maillard Reactions: Recent Studies on the Browning Reaction Mechanism and the Development of Antioxidants and Mutagens. Advances in Food Research, 32, 115-184 https://doi.org/10.1016/s0065-2628(08)60287-6

Nawirska-Olszańska, A., Kita, A., Biesiada, A., Sokół-ŁẸtowska, A., Kucharska A.Z. (2013). Characteristics of antioxidant activity and composition of pumpkin seed oils in 12 cultivars. Food Chemistry, $139(1-4), 155-161$ https://doi.org/10.1016/j.foodchem.2013.02.009

Neđeral, S., Škevin, D., Kraljić, K., Obranović, M., Papeša, S., Bataljaku, A (2012). Chemical composition and oxidative stability of roasted and cold pressed pumpkin seed oils. J. Am. Oil Chem. Soc. 89, 1763-1770 https://doi.org/10.1007/s11746-012-2076-0

Nederal, S., Petrovic, M., Vincek, D., Pukec, D., Škevin, D., Kraljić, K. Obranović, M. (2014). Variance of quality parameters and fatty acid composition in pumpkin seed oil during three crop seasons. Ind Crop Prod. 60, 15-21. https://doi. 10.1016/j.indcrop.2014.05.044 
Nguyen, M.P. (2020). Antioxidant attribute of pumpkin (Cucurbita L.) seed and oil by thermal treatment Journal of Global Pharma Technology, 12 (8), $27-31$

Paul, S., \& Mittal, G. S. (1996). Dynamics of fat/oil degradation during frying based on optical properties. Journal of Food Engineering, 30 (3-4), 389403.https://doi.org/10.1016/S0260-8774(96)00020-9

Potočnik, T., Rak Cizej, M., Jože Košir, I. (2018). Influence of seed roasting on pumpkin seed oil tocopherols, phenolics and antiradical activity. J. Food Compos. Anal. 69, 7-12. https://doi.org/10.1016/j.jfca.2018.01.020

Raczyk, M., Siger, A., Radziejewska-Kubzdela, E., Ratusz, K., \& Rudzinska, M. (2017). Roasting pumpkin seeds and changes in the composition and oxidative stability of cold-pressed oils. Acta Scientiarum Polonorum, Technologia Alimentaria, 16 (3), 293-301. https://doi.org/10.17306/J.AFS.0494

Ramírez-Anaya, J. del P., Samaniego-Sánchez, C., Castañeda-Saucedo, M. C., Villalón-Mir, M., López-García de la Serrana, H. (2015). Phenols and the antioxidant capacity of Mediterranean vegetables prepared with extra virgin olive oil using different domestic cooking techniques. Food Chemistry, 188, 430-438. https://doi.org/10.1016/j.foodchem.2015.04.124

Ramírez-Anaya, J. del P., Castañeda-Saucedo, M. C., Olalla-Herrera, M., VillalónMir, M., Serrana, H. L.-G de la, \& Samaniego-Sánchez, C. (2019). Changes in the Antioxidant Properties of Extra Virgin Olive Oil after Cooking Typical $\begin{array}{lllll}\text { Mediterranean } & \text { Vegetables. } & \text { Antioxidants, } & 8 & \text { (8), } 246 .\end{array}$ https://doi.org/10.3390/antiox8080246

Rexhepi, F., Surleva, A., Hyseni, A., Bruçi, M., Kodraliu, B. (2019). Comprehensive Investigation of Thermal Degradation Characteristics and Properties Changes of Plant Edible Oils by FTIR-Spectroscopy. Acta Chem. IASI, 27 (2), 263-286. https://doi.org/10.2478/achi-2019-0017

Samaniego-Sánchez, C., Martín-del-Campo, S. T., Castañeda-Saucedo, M. C., Blanca-Herrera, R. M., Quesada-Granados, J. J., e Ramírez-Anaya, J. P. (2021). Migração de Compostos Funcionais de Óleo Virgem de Abacate durante a Cozinha Doméstica de Berinjelas. Alimentos, 10, 1790.

Schmitz, F. R. W., Samaniego-Sánchez, C., Tedeschi, P., Maietti, A., Shariati, M. A., Hleba, L., Bertoli, S. L., \& Krebs de Souza, C. (2021). Fatty acid profile and antioxidant capacity of Oryza sativa L. (japônica subspecies) marketed in Italy and Brazil: a comparison. Journal of Microbiology, Biotechnology and Food Sciences, 11(1), e4842. https://doi.org/10.15414/jmbfs.4842

Siegmund, B., \& Murkovic, M. (2004). Changes in chemical composition of pumpkin seeds during the roasting process for production of pumpkin seed oil (Part 2: volatile compounds). Food Chem. 84, 367-374. https://doi.org/10.1016/S03088146(03)00241-3

Singh, P. R., Gupta, D. S., \& Bajpai, K. S. (1981). In: Experimental Organic Chemistry. Tata McGraw-Hill. 2: 301.

Veronezi, C. M., \& Jorge, N. (2012). Bioactive Compounds in Lipid Fractions of Pumpkin (Cucurbita sp) Seeds for Use in Food. Journal of Food Science, 77 (6), C653-C657. $\quad$ http://dx.doi.org/10.1111/j.17503841.2012.02736.x

Vlachos, N., Skopelitis, Y., Psaroudaki, M., Konstantinidou, V., Chatzilazarou, A., Tegou, E. (2006). Applications of Fourier transform-infrared spectroscopy to edible oils. Analytica Chimica Acta. (573-574), 459-465. http://doi:10.1016/j.aca.2006.05.034.

Whitfiel, F. B. (1992). Volatiles from Interactions of Maillard Reactions and Lipids. Critical Reviews in Food Science and Nutrition, 31 (1/2):I-58 http://dx.doi.org/10.1080/10408399209527560.

Zahir, E., Saeed, R., Hameed, M. A., \& Yousuf, A. (2017). Study of physicochemical properties of edible oil and evaluation of frying oil quality by Fourier Transform-Infrared (FT-IR) Spectroscopy. Arabian Journal of Chemistry, 10, S3870-S3876. http://dx.doi.org/10.1016/j.arabjc.2014.05.025 